\title{
Predicting IJVs' effectiveness based on their autonomy levels and the characteristics of their parent companies
}

\author{
William Newburry ${ }^{1}$, Orly Yeheskel ${ }^{2}$, Yoram Zeira ${ }^{3}$ \\ (1. College of Business Administration, Florida International University, Miami, FL 33199, USA; \\ 2. The Academic College of Tel Aviv Yaffo, Yaffo 61083, Israel; \\ 3. Faculty of Management, Tel-Aviv University, Tel Aviv 69978, Israel)
}

\begin{abstract}
Separate research streams have identified relationships between IJV autonomy and IJV effectiveness, and between functional/dysfunctional parent-company differentiation and IJV effectiveness. This study attempts to integrate these two literature streams by examining how these two sets of independent variables interact in terms of predicting IJV effectiveness. Results partially support our hypotheses that the autonomy-effectiveness relationship is less positive with greater functional differentiation and more positive with greater dysfunctional differentiation. The results provide strong support for our hypotheses that activities closer to the local operating environment will influence these relationships such that autonomy becomes more important to effectiveness when an activity has strong local ties.
\end{abstract}

Key words: joint venture; HRM; autonomy; differentiation; effectiveness

International joint ventures (IJVs) inherently involve decisions regarding how much integration and coordination are needed between parent companies and their IJVs, and also between parent companies themselves. Decisions must be made regarding how strong of bridges to construct between the various parties in the IJV system, based upon expectations regarding in which cases these bridges are more closely associated with IJV effectiveness. Examining relationships between IJVs and their parents, research has found significant associations between IJV autonomy and IJV effectiveness, particularly with respect to locally-embedded activities (Hill \& Hellriegel, 1994; Taggart \& Hood, 1999; Newburry, et al., 2003). Looking at relationships between IJV parents, separate research has found that differences between IJV parents could be either functional or dysfunctional in terms of predicting IJV effectiveness (Parkhe, 1991; Yeheskel, et al., 2001; Mohr \& Puck, 2005; Meschia \& Riccio, 2008). This study attempts to integrate these two literature streams by examining how these two sets of independent variables interact in terms of predicting IJV effectiveness, i.e., it examines whether there is a significant interaction of IJV autonomy with functional and dysfunctional parent company differentiation in predicting IJV effectiveness.

Combining the theoretical bases behind the above two sets of studies is important for multiple reasons. First, IJV scholars have noted the need to address the interests of different parties when studying IJV effectiveness (e.g., Osland \& Cavusgil, 1998; Luo \& Park, 2004; Madhok, 2006). The IJV autonomy studies mentioned above, in

William Newburry, Ph.D., College of Business Administration, Florida International University; research field: international management.

Orly Yeheskel, Ph.D., The Academic College of Tel Aviv Yaffo; research field: international management.

Yoram Zeira, Ph.D., Faculty of Management, Tel-Aviv University; research field: international human resource management. 
effect, address the interactions between parent companies and their IJVs, and suggest one way in which these interactions influence IJV effectiveness. The above IJV parent company differentiation studies examine the interactions between parent companies in the IJV system, and how these interactions influence effectiveness. By examining these two sets of relationships simultaneously, a more complete understanding of the IJV system can be obtained.

Second, our study builds upon the IJV control and autonomy literatures (e.g., Geringer \& Hebert, 1989; Lyles \& Reger, 1993; Lovett, Perez-Nordtvedt \& Rasheed, 2009) by examining a major contingency factor that influences the degree to which autonomy is important in effective IJV management. Thus, our results might partially reconcile the debate regarding when more autonomy and less control is beneficial (and vice versa).

Third, our study builds upon the literature examining the effects of dissimilarities between IJV parents (e.g., Parkhe, 1991; Blomqvist, et al., 2005; Kabiraj \& Chowdhury, 2008) by applying the concept of parent company dissimilarity to an important area of IJV management-the decision regarding appropriate autonomy levels.

Fourth, by examining potentially universal IJV characteristics (e.g., autonomy and parent dissimilarity) alongside the interaction of these characteristics, this manuscript addresses questions regarding whether the appropriateness of certain management characteristics is contingent upon a particular IJV situation.

Finally, our study focuses on a large sample of IJVs operating in China, an important FDI destination and research context (Bjorkman, Smale, Sumelius, Suutari \& Lu, 2008; Dong \& Glaister, 2006). Despite the popularity of Sino-foreign joint ventures, their management remains problematic (Demir \& Soderman, 2007; Nippa, et al., 2007). While our overall goal is to develop theory that applies cross-culturally, as we examine effects of asymmetry between IJVs partners in China, it might also assist the line of research looking to understand the unique characteristics of this area.

An IJV is defined herein as a separate legal organizational entity representing the partial holdings of two or more parent firms, in which the headquarters of at least one is located outside the country of the joint venture operation. This entity is subject to the joint control of its parent firms, each of which is economically and legally independent of the other (Shenkar \& Zeira, 1987).

In the next section, we outline our theoretical framework and the paper's main hypotheses. Following this, we present our research methodology. A presentation and discussion of our results follows. The paper concludes with suggestions for future research.

\section{Theory and hypotheses development}

The basic model guiding this study follows as Fig. 1. While direct relationships of IJV autonomy and parent company differentiation with IJV effectiveness are indicated within the model, this manuscript is primarily concerned with the interaction between these two sets of variables as the direct relationships have been addressed elsewhere (e.g., Hill \& Hellriegel, 1994; Yeheskel, et al., 2001). These interactions will be discussed next.

\subsection{Functional differentiation and IJV autonomy}

The theory of partner asymmetry or differentiation (e.g., Harrigan, 1988; Buckley \& Casson, 1988) notes that partners in an IJV will generally stay together as long as the partners need each other and the venture stays successful. Numerous prior studies have examined the effects of parent dissimilarities, particularly with respect to culture (e.g., Hanvanich, Miller, Richards \& Cavusgil, 2003; Brouthers \& Bamossy, 2006; Yamin \& Golesorkhi, 2010), generally finding negative effects, although Mohr and Puck (2005) focus on functional diversity. However, 
for partners to benefit from associating with each other, it is essential that each partner brings a distinct contribution to the IJV. Accordingly, for the purpose of this study, parent company differentiation is defined simply as the degree to which IJV parents are relatively similar or different with respect to a set of basic attributes or characteristics that could influence IJV effectiveness. Each parent in an IJV contributes its own bundle of attributes and resources to the venture (e.g., Chen, Newburry \& Park, 2009), making parent company differentiation inherent in IJVs. Thus, IJV parents will logically differ more or less on various attributes. In an early study of parent company differentiation, Parkhe (1991) developed a typology of interfirm diversity and its impact on global strategic alliance (GSA) longevity and effectiveness, proposing that two types of diversity influence GSA performance. Type I diversity includes the interfirm differences that GSAs are created to exploit, that is, "the reciprocal strengths and complementary resources furnished by the alliance partners, differences that actually facilitate the formulation, development, and collaborative effectiveness of GSAs”. Yeheskel, et al (2001) labeled this type of differentiation between parent firms as functional differentiation. It includes the differences between IJV partners that can bring benefits to the IJV. For example, Yeheskel, et al (2001) found that differentiation in parent company industries was functional in terms of influencing IJV effectiveness, presumably because dissimilarities in parents' core industries are imperfectly mobile and not easily copied by their IJV partners (see also, Barney, 1991, Regarding the resource based view). Consequently, these differences may lead to compatibility and collaboration as opposed to competition that may occur when parents share the same industry. According to the same line of argument, Blomqvist, et al (2005) claimed that at best, asymmetry brings major benefits to collaborative firms, but it may also become the basis of dissimilar orientation towards informal and formal governance methods, which makes managing the collaboration and reaching goals more complex.

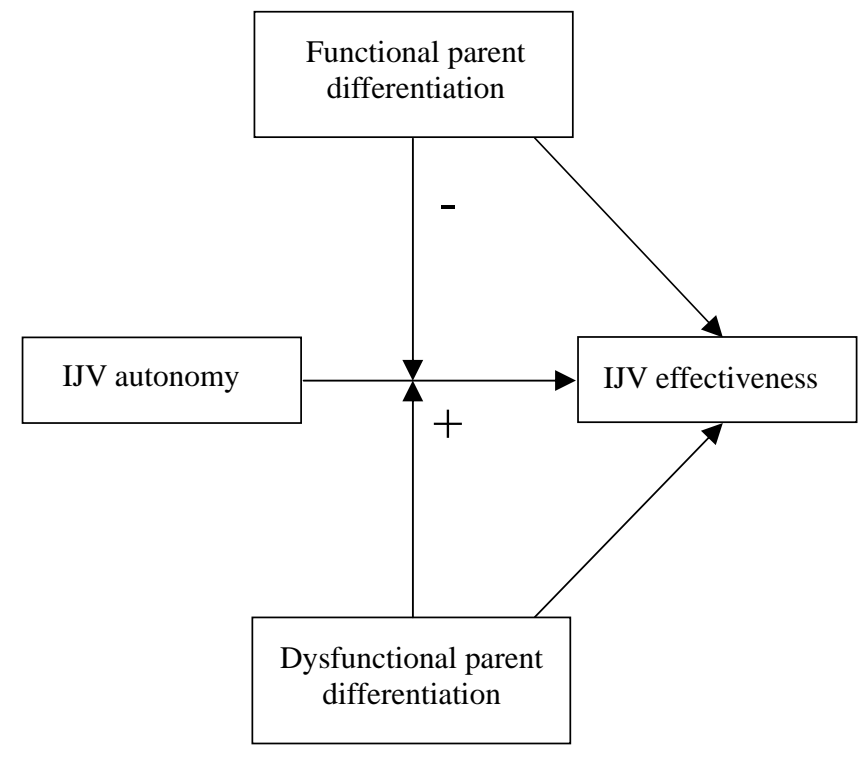

Fig. 1 Basic study model

Notes: A “-” hypothesizes that IJV autonomy benefits will be lower in cases of functional parent differentiation, while a “+” hypothesizes that IJV autonomy benefits will be greater in cases of dysfunctional parent differentiation.

For the purpose of this examination, IJV autonomy is defined as "the degree of decision making latitude allowed to the joint venture management by the partners” (Hill \& Hellriegel, 1994). The fact that powerful arguments can be made both in favor of and against granting IJV autonomy indicates that autonomy might be a 
multidimensional construct, as has also been suggested for the related concept of control (Luo, Shenkar \& Nyaw, 2001; Cardinal, Sitkin \& Long, 2004; Lovett, Perez-Nordtvedt \& Rasheed, 2009).

Research in the area of IJV autonomy suggests the necessity of granting autonomy to IJVs in order for the IJVs to escape problems of conflicting direction from parents (Hamill \& Hunt, 1993; Barden, Steensma \& Lyles, 2005). Differences between the positions of parents can lead to role conflict and role ambiguity (Katz \& Kahn, 1978; Shenkar \& Zeira, 1992) among IJV managers. Role conflict exists when the expectations of role senders (e.g., IJV parents) and role receivers (e.g., IJV managers) are contradictory. Role ambiguity exists when the expectations of role senders and role receivers are unclear. Previous research suggests that these two conditions may be exemplified when certain differences between parents are highly pronounced (e.g., Yeheskel, et al., 2001), which may be particularly applicable in IJVs involving both developed and emerging market parent firms. Within this manuscript, it is suggested that the effect of differences between parents may vary depending upon whether parent company differences are functional or dysfunctional. When differences between IJV parents are functional, it is suggested here that conflicting direction leading to role conflict and ambiguity problems may be less of a concern since these are the differences between partners that bring benefits to an IJV. In other words, these types of differences may be less likely to produce role conflict and role ambiguity among IJV managers since they are expected as part of the purpose of the IJV partnership. Since they are expected, systems may be in place to capture the benefits of these differences, and/or specific global competencies may be developed to better manage tensions and differences (e.g., Levy, Beechler, Taylor \& Boyacigiller, 2007; Furuya, Stevens, Bird, Oddou \& Mendenhall, 2009). Accordingly, the benefits of autonomy might be weaker when these differences are present. Granting IJV autonomy might even hinder the full realization of these benefits by isolating the IJV from these differences. For example, in IJVs where parents each contribute a different knowledge base associated with the parent belonging to a different industry, specific IJV processes may be needed to ensure effective knowledge transfer (Chen, Newburry \& Park, 2009). Thus, IJV autonomy may hinder parent company knowledge from being integrated into IJV operations, preventing the very synergies an IJV was designed to capture.

Accordingly, hypothesis 1 is proposed as follows:

Hypothesis 1: Functional differentiation will moderate the autonomy-effectiveness relationship such that the interaction will be negatively related to IJV effectiveness.

Indro and Richards (2007) found that important joint venture relationships may be moderated by the type of joint venture activity being performed. Recent studies have found strong relationships between IJV autonomy and IJV effectiveness with respect to autonomy to develop human resource management (HRM) practices independently (e.g., Newburry, et al., 2003). A basic assumption of the strategy literature notes that strategic business plans are often closely associated with MNC headquarters, which maintain responsibility for coordinating a firm's global operations (e.g., Tallman, 2009), while the HRM literature highlights the importance of adapting HR practices to local environmental expectations (Law, Song, Wong \& Chen, 2009). These findings suggest that autonomy may be more strongly associated with IJV effectiveness when IJVs are conducting activities that are more closely associated with the local environment. This reasoning is consistent with other theories in the international business literature. For example, integration-responsiveness theory (e.g., Prahalad \& Doz, 1987; Bartlett, 1986) posits that multinational corporations involved in industries requiring significant local adaptation should adopt structures that allow their subsidiaries greater local autonomy in their operations. Moreover, Bartlett (1986) specifically details how autonomy decisions could vary depending upon specific activities within a company. 
Based upon the above discussion, it could be expected that the nature of the hypothesis 1 interaction will change based upon the particular activity which is being performed relatively more or less autonomously. In particular, as IJV activities become more closely related to the IJV's local operating environment, the autonomy-effectiveness relationship may become stronger since these activities require greater local adaptation to be performed effectively, due to their higher degree of embeddedness in the local environment (e.g., Zaheer \& Mosakowski, 1997). In turn, conflict between the needs to integrate with their parents and to adapt locally may weaken the potential benefits of functional differentiation by creating role conflict and ambiguity among IJV managers with respect to locally sensitive activities. On the one hand, IJV managers may realize the need to coordinate closely with their parent companies to obtain the expected benefits of the functional differentiation. On the other hand, they may also feel pressure to adapt to locally-based activities in order to maintain legitimacy in their local environment (e.g., Zaheer \& Mosakowski, 1997; Trevino, Thomas \& Cullen, 2008). Because of this potential conflict, it is expected that the functional differentiation-autonomy interaction described in hypothesis 1 will have a less negative effect when an activity requiring high local adaptation is considered.

For example, human resource management (HRM) activities generally require significant local adaptation to comply with local labor laws and expectations, and to ensure venture performance (e.g., Fey, Morgulis-Yakushev, Park \& Björkman, 2009). For this type of activity, the benefits of functional differentiation may be less than for activities more closely associated with an IJV's parent companies (e.g., strategy formulation), since activities associated with IJV parents (and their combined goals) are more likely to be the focus of differentiation benefits. Moreover, in addition to potentially weaker benefits from functional differentiation for locally-based activities (such as HRM), the potential to create negative consequences (such as alienated employees, e.g., Brannen \& Peterson, 2009) for the IJV by not adapting to local expectations appears to be greater.

Accordingly, hypothesis 2 is proposed as follows:

Hypothesis 2: The relationship proposed in hypothesis 1 will be less negative when autonomy relates to an activity more closely associated with the IJV's local operating environment (vs. being associated with the parent companies).

\subsection{Dysfunctional differentiation and IJV autonomy}

Parkhe's (1991) Type II diversity relates to "the differences in partner characteristics that often negatively affect the longevity and effective functioning of GSAs”. Yeheskel, et al (2001) referred to this as dysfunctional differentiation. This category of variables relates to differences among IJV parents that cause an IJV to function poorly since they interfere with effective IJV management. Negative asymmetries are associated with cases where a dysfunctional differentiation variable impedes integration within the system of an IJV and its parents. An example of a dysfunctional differentiation variable is goal differentiation. Dissimilarities in parents' goals, especially the existence of contradictory goals of a hidden agenda type, can create serious IJV management problems and disrupt daily activities, since they distract IJV management from their pursuit of an IJV's stated objectives (Yeheskel, et al., 2001; Luo, Shenkar \& Nyaw, 2001). Other studies focus on other dissimilarities as a source of problematic effects on IJVs (e.g., Yamin \& Golesorkhi, 2010; Brouthers, Brouthers \& Wilkinson, 1995). For example, Kabiraj, et al (2005) found that country specific cultural characteristics and partner asymmetry are the fundamental cause of joint ventures instability and breakdown. Kabiraj and Chowdhury (2008), studying joint ventures between local firms from LDCs and foreign multinationals (MNCs), found that differences in technology levels between partners and the availability of new technology can trigger a joint venture breakdown.

When differences between IJV parents are dysfunctional, this may increase the chance that an IJV will 
receive confusing and potentially conflicting directions from its parents. Accordingly, this may be a source of both role conflict and role ambiguity for IJV managers, causing them to expend undue energies in attempts to reconcile these differences or to develop programs and intervention capabilities to address these issues (e.g., Brouthers \& Bamossy, 2006; Brannen \& Peterson, 2009) that could be more constructively used towards the purpose of achieving the IJV's objectives. When this is the case, autonomy may become more necessary for the IJV to operate effectively without being hindered by the role conflict and role ambiguity that often accompany conflicting parent directions (Shenkar \& Zeira, 1992). For example, when dysfunctional differentiation exists with respect to parent company goals (as discussed above), autonomy may help an IJV to overcome the problems of dealing with potentially conflicting and ambiguous parent company directions. Discussing these same relationships between differences, autonomy, and performance, Pangarkar and Klein (2005) argued that the exercise of control in IJVs increases the performance only when there are large differences between partners.

Accordingly, hypothesis 3 is proposed as follows:

Hypothesis 3: Dysfunctional differentiation will moderate the autonomy-effectiveness relationship such that the interaction will be positively related to IJV effectiveness.

As noted earlier, important IJV relationships may be moderated by the activity being performed (Indro \& Richards, 2007). As was the case of hypothesis 2 above, it is expected that the interaction between IJV autonomy and parent company differentiation will differ based upon the particular activity for which autonomy is being granted. Birkinshaw, Hood and Young (2005) argued that strong local competitive environments enable managers to achieve sufficient autonomy to secure their subsidiaries' performance (see also Young \& Taveres, 2004; Vachani, 1999). It is again suggested that as IJV activities become more closely related to the IJV's local operating environment, the autonomy-effectiveness relationship will become stronger. In this particular case, the autonomy push from an activity being closely associated with the local environment may reinforce the autonomy push caused by dysfunctional differentiation. Thus, the interaction of autonomy with dysfunctional differentiation will produce an even stronger relationship than the one proposed in hypothesis 3 when an activity is more locally embedded. For example, while dysfunctional goal differentiation promotes a positive relationship between autonomy and effectiveness, this relationship may become even stronger when autonomy in a locally-based activity (such as HRM; e.g., Fey, Morgulis-Yakushev, Park \& Björkman, 2009) is being performed versus activities more closely associated with an IJV's parent companies (such as strategy formulation). This may occur because both these circumstances promote autonomy and the two autonomy pulls reinforce each other.

Accordingly, hypothesis 4 is proposed as follows:

Hypothesis 4: The relationship proposed in hypothesis 3 will be even more positive when autonomy relates to an activity more closely associated with the IJV's local operating environment (vs. being associated with the parent companies).

\section{Methodology}

The study reported here is a part of a larger international comparative study aimed at understanding ways of increasing IJV effectiveness. All of the IJVs in our sample fit Shenkar and Zeira's (1987) IJV definition, as cited in the introduction to this manuscript. This study's JV sample was identified as follows. First, the American Chamber of Commerce in Hong Kong provided a list of American MNCs with JVs in China and a regional headquarters (HQ) in Hong Kong. The Hong Kong General Chamber of Commerce provided a similar list of West 
European MNCs. The resulting sample of 26 regional HQ was then contacted and requested to participate in the study. All but one regional HQ agreed to participate. Each of the resulting 25 regional HQ provided a list of their JVs in China established at least three years prior to our questionnaire administration. JVs less than three years of age were not included since JVs may have significant start-up problems (e.g., role novelty, Katz \& Kahn, 1978) in their first years of operation which might be unrelated to appropriate management styles (Bleeke \& Ernst, 1993). This resulted in $153 \mathrm{JVs}$, all of which fit our JV definition. JV CEOs were then contacted and asked to complete our questionnaire. As the leaders of their IJVs, CEOs are generally regarded as key informants (e.g., Gupta, Shaw \& Delery, 2000), and the best-informed sources regarding IJV operations. All eventually filled out the questionnaire, which was returned directly to the researchers.

After receiving all the completed questionnaires from the JVs' CEOs, the CEOs of the 25 regional HQ were contacted and requested to complete the same items. Overall, we received 153 questionnaires from 25 regional HQ evaluating $153 \mathrm{JVs}$ operating in China. This methodology was endorsed and coordinated with the main HQs of the 25 MNCs. Regional HQ responses were used to verify CEO response accuracy by comparing the two sets of responses, with insignificant differences found between IJV CEOs and their regional headquarters in terms of their IJV effectiveness evaluations. Questionnaire responses were supplemented with secondary data regarding the IJVs and their operating environments.

The JVs in our sample are involved in a variety of industries and services and employ between 8 and 9500 employees (mean: 986 employees). The majority (117) are owned by two parent companies; 26 have three parents; 7 have four parents; 2 have five parents and 1 has six parents. None of the JVs has parent-companies located in more than four different countries.

\subsection{IJV effectiveness measures}

Out dependent variable is IJV effectiveness. Based upon content analysis of frequently mentioned goals in IJV documents of incorporation, we asked our questionnaire respondents to rate the extent to which their IJVs accomplished the following measures on a 5-point scale, ranging from 5 (strongly agree) to 1 (strongly disagree): (1) meet the expectations of their stakeholders; (2) have a growing market share; (3) are financially profitable; (4) meet targeted growth objectives; and (5) meet targeted profit objectives. These measures are widely accepted (Killing, 1983; Yeheskel, et al., 2001), and their results have been found to correlate significantly with financial measurements of the same variables (Dess \& Robinson, 1984; Geringer \& Hebert, 1991). Additionally, using a variety of measures helps account for the fact that companies from different countries often pursue different objectives (e.g., Fenton-O’Creevy, Gooderham \& Nordhaug, 2008), and that IJV performance is multidimensional in nature (Nielsen, 2007). For our sample, the internal reliability of the five items was quite high (Cronbach alpha=0.90), suggesting a common underlying factor. Accordingly, EFFECTIVE is a composite variable that was created by averaging across these five items of our survey.

\subsection{Autonomy measures}

The following two autonomy variables were based upon questionnaire responses on a 5-point scale. FORMPLAN measures the degree to which an IJV formulates its strategic business plan independently of its parent organizations. LOCALHRM measures the degree to which the IJV develops human resource practices independently based on host culture characteristics. While the benefits of single-versus multiple-item measures are debated, single-item measures have been found equally or even more preferable in terms of construct validity in many contexts (e.g., Ganzach, 1998; Scarpello \& Campbell, 1983). 


\subsection{Differentiation measures}

The following differentiation measures were individually generated and then aggregated into composite functional and dysfunctional differentiation measures in a manner consistent with Yeheskel, et al (2001). Within that study, each differentiation measure was individually empirically related to IJV effectiveness. Based upon whether the individual measures were positively or negatively associated with IJV effectiveness, they were then classified as either functional differentiation or dysfunctional differentiation. In the event that a measure was not clearly related to IJV effectiveness either way, it was dropped from the analysis. In this particular analysis, this applied to two Hofstede (2001) cultural dimensions: power distance and long term orientation. Composite functional and dysfunctional differentiation variables were then created based upon the means of the variables (standardized) assigned to each of these categories. Use of composite functional and dysfunctional differentiation variables helps to establish a general understanding of the interaction of these variables with IJV autonomy. Additionally, utilizing composite variables allows this study's results to be more easily compared to the previous Yeheskel, et al (2001) results.

Since about a third of the IJVs in our sample had more than two parent organizations, calculating differences between parents using a simple mathematical difference would have elicited only differences between extreme values. Because of this and because the number of IJV partners has important performance implications (e.g., Garcia-Canal \& Sanchez-Lorda, 2007), when appropriate, a standard deviation between all parents was used to calculate this study's differentiation variables in a manner consistent with Yeheskel, et al (2001). Utilizing a standard deviation elicits the differences among all values in the distribution.

\subsection{Functional differentiation components}

Based upon the above analysis, the following differentiation components of the parent companies were classified as functional for this study: industry type differentiation, differentiation in parent company size, equity differentiation, ownership type differentiation and differentiation in the cultural dimension of masculinityfemininity.

Industry type differentiation was measured by respondents' ratings on a 5-point scale.

Parent size differentiation was measured as the standard deviation in the number of employees of the various parent organizations.

Equity differentiation was measured as the standard deviation of the equity distribution of the various parents.

Ownership type differentiation was calculated based upon the following three ownership types: publicly owned, privately owned and state-owned. This differentiation measure was given the value of 1 when all parents of each IJV had the same ownership type (indicating no differentiation between parents); the value of 2 when the ownership type of each IJV was split between publicly owned and privately owned parents (suggesting medium differentiation); and the value of 3 in all other cases (indicating high levels of differentiation based on the assumption that state-owned parent companies differ significantly from the public and private ownership types).

Masculinity differentiation was measured as the standard deviation between the scores of the parent organizations across Hofstede’s masculinity-femininity cultural dimension (Hofstede, 2001).

\subsection{Dysfunctional differentiation components}

Based upon the above analysis, the following differentiation components of the parent companies were classified as dysfunctional for this study: goal differentiation, reputation differentiation and differentiation in the cultural dimensions of uncertainty avoidance and individualism-collectivism.

Goal differentiation was measured by respondents' ratings on a 5-point scale. 
Reputation differentiation was calculated as an arithmetic average of differences between respondents' ratings of the international and local reputations of the parent organizations as measured on a 5-point scale.

Uncertainty avoidance and Individualism differentiation were measured as the standard deviations between the scores of the parent organizations across each of Hofstede's uncertainty avoidance and individualism dimensions (Hofstede, 2001).

\subsection{Control variables}

The following control variables were used in this study. IJVAGE represents the IJV's age in years. Previous authors have concluded that there will be a positive correlation between an IJV's age and its effectiveness (Hill \& Hellriegel, 1994). IJVSIZE is measured as the log of the number of employees in the IJV. Larger IJVs may either have more resources (increasing their effectiveness), or may be more bureaucratic (decreasing their effectiveness) (Chen, et al., 2009; Hannan \& Freeman, 1977). INCORP measures on a 5-point scale the degree to which an IJV has detailed documents of incorporation. Some common advice for IJV managers is to ensure that IJV documents of incorporation are detailed and constantly updated. CLEAR OBJECTIVES measures the extent to which an IJV has clear objectives from its parents on a 5-point scale. Having clear objectives allows the IJV to function with less confusion and wasted effort (Dobkin, et al., 1994), thus increasing effectiveness. RESOURCE DEPENDENCE measures the extent to which an IJV is dependent on its parents for critical resources based on a 5-point scale. NUMBER OF PARENTS refers to the number of parent companies that own equity in an IJV. DOMINANT PARENT measures the degree to which an IJV has a dominant parent with appointees responsible for running the venture independently regardless of the parent's equity ownership, as assessed by respondents on a 5-point scale. This variable has been found highly significant in prior IJV studies (e.g., Newburry \& Zeira, 1999). INDUSTRY is a series of $1 / 0$ dummy variables coded based upon whether the IJV operates in a heavy industry, light industry or service industry.

\subsection{Analysis}

We used multiple ordinary least square (OLS) regressions to test the hypotheses. Multiple linear regression analysis was appropriate for this study because IJV autonomy and parent differentiation were simultaneously related to IJV performance, and because those hypothesized relationships could be recursive. In order to better understand our results, we also conducted several post-hoc analyses, as described below.

\section{Results}

Table 1 reports the mean values of the study variables, as well as their standard deviations and correlation coefficients. Individual components of the functional and dysfunctional differentiation variables are reported along with the composite variables.

Table 2 presents the results of our regression analyses based upon the composite factors. Model 1 presents a control regression. Model 2 through Model 5 present the results of our regression analyses based on the interaction of autonomy to formulate strategy (Model 2 and Model 3) and HRM autonomy (Model 4 and Model 5) with functional differentiation. Model 6 through Model 9 present the results of our regression analyses based on the interaction of autonomy to formulate strategy (Model 6 and Model 7) and HRM autonomy (Model 8 and Model 9) with dysfunctional differentiation. As can be seen, all models are highly significant $(p<0.001)$ and have adjusted $r$-squares of at least 29 percent. 
Table 1 Descriptive statistics and Pearson correlations

\begin{tabular}{|c|c|c|c|c|c|c|c|c|c|c|c|c|c|}
\hline & Mean & Std. Dev & 1. & 2. & 3. & 4. & 5. & 6. & 7. & 8. & 9. & 10. & 11 \\
\hline 1. IJV effectiveness & 4.01 & 0.84 & 1.0 & & & & & & & & & & \\
\hline $\begin{array}{l}\text { 2. Autonomy in strategy } \\
\text { formulation }\end{array}$ & 0.70 & 0.46 & $0.26 * *$ & 1.0 & & & & & & & & & \\
\hline 3. HRM autonomy & 0.92 & 0.28 & $0.21^{* *}$ & $0.21^{* *}$ & 1.0 & & & & & & & & \\
\hline $\begin{array}{l}\text { 4. Functional parent } \\
\text { differentiation }\end{array}$ & 3.94 & 0.37 & -0.02 & 0.00 & -0.01 & 1.0 & & & & & & & \\
\hline $\begin{array}{l}\text { 5. Dysfunctional parent } \\
\text { differentiation }\end{array}$ & 3.72 & 0.41 & $-0.29 * *$ & $-0.16^{*}$ & $-0.28 * *$ & $0.19 * *$ & * 1.0 & & & & & & \\
\hline 6. IJV age & 5.01 & 3.38 & $0.33^{* *}$ & $0.21^{* *}$ & -0.02 & 0.04 & -0.08 & 1.0 & & & & & \\
\hline 7. IJV size & 2.62 & 0.56 & 0.16 & 0.11 & -0.05 & -0.05 & -0.08 & $0.39 * *$ & $=1.0$ & & & & \\
\hline 8. Clear objectives & 4.11 & 0.80 & $0.42^{* *}$ & 0.06 & -0.08 & -0.03 & $-0.18 *$ & $0.24 * *$ & $=0.15$ & 1.0 & & & \\
\hline $\begin{array}{l}\text { 9. Detailed incorp } \\
\text { documents }\end{array}$ & 3.37 & 1.26 & 0.00 & 0.06 & -0.04 & 0.13 & -0.01 & 0.03 & 0.08 & $0.17^{*}$ & 1.0 & & \\
\hline $\begin{array}{l}\text { 10. Resource } \\
\text { dependence }\end{array}$ & 3.92 & 1.11 & -0.11 & 0.11 & -0.15 & 0.06 & 0.08 & -0.05 & 0.00 & 0.14 & $0.23^{* *}$ & ${ }^{k} 1.0$ & \\
\hline 11. No. of parents & 2.31 & 0.71 & 0.00 & -0.08 & 0.10 & 0.03 & $-0.22 * *$ & 0.09 & 0.14 & -0.09 & 0.10 & -0.12 & 1.0 \\
\hline 12. Dominant parent & 4.01 & 1.17 & $0.23 * *$ & 0.03 & -0.14 & 0.10 & -0.03 & -0.04 & $-0.16^{*}$ & $0.20 *$ & -0.09 & $0.39 * *$ & $-0.28 *$ \\
\hline
\end{tabular}

Hypothesis 1 predicted that the autonomy-effectiveness relationship will be less positive when functional differentiation exists between IJV parents. Model 2 through Model 5 demonstrate mixed support for this hypothesis. In Model 2 and Model 4, significant $(p<0.001)$ base positive relationships between IJV autonomy and IJV effectiveness are demonstrated. In Model 3, the interaction term is negative and marginally significant $(p<0.10)$, thus marginally supporting the hypothesis that functional differentiation will make the autonomy to formulate strategy-IJV effectiveness relationship less positive. However, in Model 5, the interaction term for the HRM autonomy variable is positive and significant $(p<0.05)$, showing a relationship opposite to that proposed.

Hypothesis 2 predicted that the relationship proposed in hypothesis 1 will be less negative when autonomy relates to an activity more closely associated with the IJV's local operating environment than when autonomy relates to an activity more closely associated with the IJV parents. Since IJV strategy is an activity commonly associated with close parental supervision in an IJV, while HRM is an activity closely associated with the local environment, the Model 3 and Model 5 results support this hypothesis. While the autonomy to formulate strategy and functional differentiation interaction is marginally significantly negative $(p<0.10)$, the HRM autonomy interaction is actually positive and significant $(p<0.05)$.

Hypothesis 3 predicted that the autonomy-effectiveness relationship will be more positive when dysfunctional differentiation exists between IJV parents than when functional differentiation exists. Models 6 through 9 demonstrate mixed support for this hypothesis. Model 6 and Model 8 demonstrate a significant positive base relationship between IJV autonomy and IJV effectiveness ( $p<0.01$ or $p<0.001$ ). In Model 7, the interaction term is not significant, thus providing no support for hypothesis 3 with respect to autonomy to formulate strategy. In Model 9, the interaction term is positive and significant $(p<0.01)$, thus supporting the proposed relationship with respect to HRM autonomy.

Hypothesis 4 predicted that the relationship proposed in hypothesis 3 will be even more positive when autonomy relates to an activity more closely associated with the IJV's local operating environment than when 
autonomy relates to an activity more closely associated with the IJV parents. This hypothesis is supported since the interaction of HRM autonomy and dysfunctional differentiation is positive and significant $(p<0.01)$ while the interaction between autonomy to formulate strategy and dysfunctional differentiation is not significant.

In addition to the models reported above, we also computed regressions simultaneously introducing all the functional and dysfunctional interaction terms, respectively. Due to multicollinearity issues, we could not reliably run all variables together. Nonetheless, these analyses produced results that were generally consistent with those reported above.

Table 2 Composite functional and dysfunctional differentiation interactions with autonomy variables predicting IJV effectiveness

\begin{tabular}{|c|c|c|c|c|c|c|c|c|c|}
\hline Variables & Model 1 & Model 2 & Model 3 & Model 4 & Model 5 & Model 6 & Model 7 & Model 8 & Model 9 \\
\hline \multicolumn{10}{|l|}{ Control variables } \\
\hline IJV age & $\begin{array}{l}0.23 \\
(0.02)^{* *}\end{array}$ & $\begin{array}{l}0.19 \\
(0.02)^{*}\end{array}$ & $\begin{array}{l}0.29 \\
(0.02)^{* *}\end{array}$ & $\begin{array}{l}0.24 \\
(0.02)^{* * *}\end{array}$ & $\begin{array}{l}0.22 \\
(0.02)^{* *}\end{array}$ & $\begin{array}{l}0.19 \\
(0.02)^{* *}\end{array}$ & $\begin{array}{l}0.19 \\
(0.02)^{* *}\end{array}$ & $\begin{array}{l}0.24 \\
(0.02)^{* * *}\end{array}$ & $\begin{array}{l}0.22 \\
(0.02)^{* *}\end{array}$ \\
\hline IJV size & $\begin{array}{c}0.07 \\
(0.00)\end{array}$ & $\begin{array}{c}0.07 \\
(0.00)\end{array}$ & $\begin{array}{c}0.05 \\
(0.00)\end{array}$ & $\begin{array}{c}0.07 \\
(0.00)\end{array}$ & $\begin{array}{c}0.05 \\
(0.00)\end{array}$ & $\begin{array}{c}0.07 \\
(0.00)\end{array}$ & $\begin{array}{c}0.08 \\
(0.00)\end{array}$ & $\begin{array}{c}0.07 \\
(0.00)\end{array}$ & $\begin{array}{c}0.05 \\
(0.00)\end{array}$ \\
\hline Clear objectives & $\begin{array}{l}0.30 \\
(0.08)^{* * *}\end{array}$ & $\begin{array}{l}0.30 \\
(0.08)^{* * *}\end{array}$ & $\begin{array}{l}0.31 \\
(0.08)^{* * *}\end{array}$ & $\begin{array}{l}0.31 \\
(0.08)^{* * *}\end{array}$ & $\begin{array}{l}0.33 \\
(0.08)^{* * *}\end{array}$ & $\begin{array}{l}0.30 \\
(0.08)^{* * *}\end{array}$ & $\begin{array}{l}0.30 \\
(0.08)^{* * *}\end{array}$ & $\begin{array}{l}0.31 \\
(0.08)^{* * *}\end{array}$ & $\begin{array}{l}0.33 \\
(0.08)^{* * *}\end{array}$ \\
\hline $\begin{array}{l}\text { Detailed } \\
\text { incorporation } \\
\text { documents }\end{array}$ & $\begin{array}{c}0.02 \\
(0.05)\end{array}$ & $\begin{array}{l}0.01 \\
(0.05)\end{array}$ & $\begin{array}{c}0.01 \\
(0.05)\end{array}$ & $\begin{array}{c}0.03 \\
(0.05)\end{array}$ & $\begin{array}{c}0.05 \\
(0.05)\end{array}$ & $\begin{array}{c}0.02 \\
(0.05)\end{array}$ & $\begin{array}{c}0.02 \\
(0.05)\end{array}$ & $\begin{array}{c}0.03 \\
(0.05)\end{array}$ & $\begin{array}{c}0.02 \\
(0.05)\end{array}$ \\
\hline $\begin{array}{l}\text { Resource } \\
\text { dependence }\end{array}$ & $\begin{array}{l}-0.24 \\
(0.06)^{* *}\end{array}$ & $\begin{array}{l}-0.27 \\
(0.06)^{* * *}\end{array}$ & $\begin{array}{l}-0.26 \\
(0.06)^{* * *}\end{array}$ & $\begin{array}{l}-0.21 \\
(0.06)^{* *}\end{array}$ & $\begin{array}{l}-0.22 \\
(0.06)^{* *}\end{array}$ & $\begin{array}{l}-0.27 \\
(0.06)^{* * *}\end{array}$ & $\begin{array}{l}-0.28 \\
(0.06)^{* * *}\end{array}$ & $\begin{array}{l}-0.21 \\
(0.06)^{* *}\end{array}$ & $\begin{array}{l}-0.21 \\
(0.06)^{* *}\end{array}$ \\
\hline Number of parents & $\begin{array}{c}0.05 \\
(0.09)\end{array}$ & $\begin{array}{l}0.07 \\
(0.09)\end{array}$ & $\begin{array}{c}0.08 \\
(0.09)\end{array}$ & $\begin{array}{c}0.02 \\
(0.09)\end{array}$ & $\begin{array}{c}0.04 \\
(0.09)\end{array}$ & $\begin{array}{c}0.07 \\
(0.09)\end{array}$ & $\begin{array}{c}0.07 \\
(0.09)\end{array}$ & $\begin{array}{c}0.03 \\
(0.09)\end{array}$ & $\begin{array}{c}0.04 \\
(0.09)\end{array}$ \\
\hline Dominant parent & $\begin{array}{l}0.33 \\
(0.06)^{* * *}\end{array}$ & $\begin{array}{l}0.34 \\
(0.06)^{* * *}\end{array}$ & $\begin{array}{l}0.33 \\
(0.06)^{* * *}\end{array}$ & $\begin{array}{l}0.34 \\
(0.06)^{* * *}\end{array}$ & $\begin{array}{l}0.35 \\
(0.06)^{* * *}\end{array}$ & $\begin{array}{l}0.34 \\
(0.06)^{* * *}\end{array}$ & $\begin{array}{l}0.35 \\
(0.06)^{* * *}\end{array}$ & $\begin{array}{l}0.34 \\
(0.06)^{* * *}\end{array}$ & $\begin{array}{l}0.32 \\
(0.06)^{* * *}\end{array}$ \\
\hline Industry dummies & Mixed & Mixed & Mixed & Mixed & Mixed & Mixed & Mixed & Mixed & Mixed \\
\hline \multicolumn{10}{|l|}{ Independent variables } \\
\hline $\begin{array}{l}\text { Functional parent } \\
\text { diff. }\end{array}$ & & $\begin{array}{c}0.00 \\
(0.14)\end{array}$ & $\begin{array}{c}0.03 \\
(0.14)\end{array}$ & $\begin{array}{l}-0.01 \\
(0.14)\end{array}$ & $\begin{array}{l}-0.01 \\
(0.14)\end{array}$ & & & & \\
\hline $\begin{array}{l}\text { Dysfunctional parent } \\
\text { diff. }\end{array}$ & & & & & & $\begin{array}{l}-0.01 \\
(0.13)\end{array}$ & $\begin{array}{l}-0.00 \\
(0.13)\end{array}$ & $\begin{array}{c}0.02 \\
(0.13)\end{array}$ & $\begin{array}{l}-0.03 \\
(0.13)\end{array}$ \\
\hline $\begin{array}{l}\text { Autonomy in } \\
\text { strategy formulation }\end{array}$ & & $\begin{array}{l}0.21 \\
(0.13)^{* *}\end{array}$ & $\begin{array}{l}0.29 \\
(0.15)^{* * *}\end{array}$ & & & $\begin{array}{l}0.21 \\
(0.13)^{* *}\end{array}$ & $\begin{array}{l}0.24 \\
(0.16)^{* *}\end{array}$ & & \\
\hline HRM autonomy & & & & $\begin{array}{l}0.24 \\
(0.20)^{* * *} \\
\end{array}$ & $\begin{array}{c}0.18 \\
(0.22)^{*} \\
\end{array}$ & & & $\begin{array}{l}0.25 \\
(0.20)^{* * *}\end{array}$ & $\begin{array}{l}-0.16 \\
(0.43) \\
\end{array}$ \\
\hline \multicolumn{10}{|l|}{ Interaction terms } \\
\hline $\begin{array}{l}\text { Autonomy in } \\
\text { strategy formulation } \\
\text { x parent } \\
\text { differentiation }\end{array}$ & & & $\begin{array}{l}-0.16 \\
(0.24)+\end{array}$ & & & & $\begin{array}{l}-0.06 \\
(0.28)\end{array}$ & & \\
\hline $\begin{array}{l}\text { HRM autonomy } \mathrm{x} \\
\text { parent differentiation }\end{array}$ & & & & & $\begin{array}{c}0.14 \\
(0.30)^{*}\end{array}$ & & & & $\begin{array}{l}0.45 \\
(0.53) * *\end{array}$ \\
\hline Adjusted $R^{2}$ & $0.296 * * *$ & $0.330 * * *$ & $0.341^{* * *}$ & $0.345 * * *$ & $0.358 * * *$ & $0.330 * * *$ & $0.327 * * *$ & $0.346^{* * *}$ & $0.385 * * *$ \\
\hline $\mathrm{R}^{2}$ change & & $0.054^{* * *}$ & $0.015^{+}$ & $0.055^{* *}$ & $0.016^{*}$ & $0.041^{* *}$ & 0.001 & $0.056^{* *}$ & $0.041^{* *}$ \\
\hline $\mathrm{N}$ & 150 & 150 & 150 & 150 & 150 & 150 & 150 & 150 & 150 \\
\hline Model $F$ & $7.995 * * *$ & $7.704 * * *$ & $8.607 * * *$ & $8.192 * * *$ & $7.965 * * *$ & $7.706 * * *$ & $7.070 * * *$ & $8.202 * * *$ & $8.830 * * *$ \\
\hline
\end{tabular}

Notes: ${ }^{+} p<0.10 ;{ }^{*} p<0.05 ;{ }^{* *} p<0.01 ;{ }^{* * *} p<0.001 ; 2$-tailed test; Regressions present standardized beta coefficients with standard errors in parentheses. 


\section{Discussion and conclusion}

Our study results partially support our hypotheses that the autonomy-effectiveness relationship will be less positive with greater functional differentiation and more positive with greater dysfunctional differentiation. The results provide strong support for our hypotheses that activities closer to the local operating environment will influence these relationships such that autonomy becomes more important to effectiveness when an activity has strong local ties.

Paterson and Brock (2002) noted that the issue of subsidiary autonomy is also of growing importance in the general subsidiary-management research, stemming from authors who support subsidiary focused MNC perspectives (e.g., Birkinshaw, Hood \& Young, 2005; Wang, Liu \& Li, 2009). Aside from the IJV-specific autonomy rationale mentioned above, they note that autonomy can provide numerous general subsidiary benefits, largely related to local responsiveness and developing/leveraging subsidiary competencies. However, it is not a position that has been extensively tested, as cases for both autonomous and centralized corporate structures still exist. Within this manuscript, we partially reconciled this debate by examining autonomy's interaction with parent-company differentiation in predicting IJV effectiveness.

With respect to our HRM autonomy results, Law, Tse and Zhou (2003) found that effective HRM was important to firm performance in China. Part of effectively managing HRM issues is appropriate autonomy levels for various parent company configurations. Hitt, et al (2001) found an interaction between human capital and strategy in terms of predicting firm performance. Similarly, we find that human resource autonomy interacts with parent differentiation, a variable often closely related to IJV strategy, in terms of predicting IJV performance.

With respect to our results concerning autonomy to formulate strategy, our findings reiterate previous ones (e.g., Newburry, et al., 2003) that different types of autonomy have different effects on IJV effectiveness. Moreover, the results suggest that the autonomy to formulate strategy takes away benefits that might be achieved through functional differentiation.

With respect to the issue of functional and dysfunctional differentiation, our results suggest that different types of autonomy interact with different types of differentiation. In particular, HRM autonomy provides stronger benefits when dysfunctional differentiation is present, while autonomy to formulate strategy causes most harm when functional differentiation is present.

Our approach of examining interactions between autonomy and differentiation might also relate to Langfred (2004), who examined interactions between trust and autonomy in team-based settings. He found that "High trust was associated with higher team performance when individual autonomy was low but with lower performance when individual autonomy was high” (p. 385). Our functional differentiation measure may substitute for Langfred's high trust case since functional differences are beneficial, and thus, may be less feared. Moreover, similar to the author's high trust case, granting autonomy could cause differentiation benefits to go unrealized.

Luo (2003) found that control flexibility (i.e., the granting of autonomy when needed) was positively associated with IJV performance in order to allow the flexibility necessary to succeed in emerging markets. This result is consistent with our autonomy-differentiation interactions to the extent that we help delineate the specific cases when autonomy is beneficial or needed.

Inkpen and Currall (2004) discussed how trust, control and learning may coevolve in joint venture relationships. With respect to our framework, their model may apply to our functional differentiation cases, where IJV parents have a goal to benefit from the differences between each other. In these cases, parents may not find 
granting IJV autonomy beneficial, but may still be able to alter their control methods between formal controls, which rely upon the ability to measure outcomes and influence processes, and social controls, which rely on social interactions and creating shared values (Cardinal, et al., 2004). Depending upon their relationship with their partners, in functional differentiation cases, altering the control method may still provide positive benefits for the IJV parents.

\subsection{Academic contributions and implications}

This study contributes to the international joint venture management literature in a number of ways. First, it contributes to the IJV control and autonomy literature (e.g., Geringer \& Hebert, 1989; Hill \& Hellriegel, 1994; Lovett, Perez-Nordtvedt \& Rasheed, 2009) by demonstrating conditions when autonomy is more (or less) important based upon a major contingency factor: The level of functional and/or dysfunctional differentiation that exists between IJV parents. By incorporating these interactions into existing theory, it may be possible to develop a more complete understanding of the mechanisms underlying IJV autonomy.

Second, related to the first point above, the results contribute to the autonomy literature by demonstrating the differential effects of different types of autonomy, as has been previously suggested within Newburry, Zeira and Yeheskel (2003). The distinction in results between strategy autonomy and HRM autonomy further suggests that a continuum of activities might be developed based upon the degree to which they might be centrally controlled by the IJV parents and the degree to which they might benefit from IJV autonomy.

Third, this study builds upon literature examining the effects of dissimilarities between IJV parents in general (e.g., Parkhe, 1991; Yeheskel, et al., 2001) and regarding selected specific variables (e.g., Beamish \& Jung, 2005; Yamin \& Golesorkhi, 2010) by applying the concept of parent company dissimilarity to an important IJV management area. In doing so, the manuscript further refined this theoretical area by specifying conditions under which functional and dysfunctional differentiation between IJV parents vary in their impact on IJV effectiveness.

Fourth, IJV scholars have noted the need to address the interests of multiple parties when studying IJV effectiveness (e.g., Osland \& Cavusgil, 1998; Luo \& Park, 2004). By simultaneously examining (1) the interaction between an IJV and its parents through the concept of autonomy, and (2) the interaction between parents through the concept of parent company differentiation, this study produces a more complete understanding of the IJV system than might be obtained by examining only one of these relationships at a time.

Fifth, by examining potentially universal IJV characteristics (e.g., autonomy and dissimilarity) alongside the interaction of these characteristics, this manuscript addresses questions regarding whether the appropriateness of certain management characteristics is contingent upon a particular IJV's situation.

\subsection{Limitations and suggestions for future research}

While our results provide insights into IJV autonomy and IJV parent differentiation, it is not without limitations, creating future research opportunities. First, more research is needed into the temporal aspects of the autonomy variables and their impact on IJV effectiveness. While it can be argued that our differentiation variables precede our autonomy and effectiveness variables, causality between autonomy and effectiveness is not clear. Second, more research is needed regarding time-based changes to autonomy preferences. Salk and Shenkar (2001) found that IJV CEO social identification patterns changed over time, and that these influenced CEO views regarding IJV independence. Likewise, Zhang and Li (2001) and Wang and Nicholas (2007) found changes in IJV control designs over time based upon IJV performance. It might also be the case that interactions between our dissimilarity and autonomy variables change over time. Third, while our current research indicates the differential impact of two important autonomy dimensions, the multidimensional nature of the autonomy construct needs to be 
further refined and developed. Fourth, further research should examine whether regional differences (Rugman \& Oh, 2010) exist which impact the autonomy-differentiation relationship. Fifth, further studies might examine whether these relationships are moderated by environmental variables such as national culture or institutions (e.g., Trevino, Thomas \& Cullen, 2008).

\section{References:}

Barden, J. Q., Steensma, H. K. \& Lyles, M. A.. (2005). The influence of parent control structure on parent conflict in Vietnamese international joint ventures: An organizational justice-based contingency approach. Journal of International Business Studies, 36, 156-174.

Barney, J. B.. (1991). Firms resources and sustained competitive advantage. Journal of Management, 17(1), 99-120.

Barr, P. S. \& Glynn, M. A.. (2004). Cultural variations in strategic issue interpretation: Relating cultural uncertainty avoidance to controllability in discriminating threat and opportunity. Strategic Management Journal, 25, 59-67.

Bartlett, C. A.. (1986). Building and managing the transnational: The new organizational challenge. In: Porter, M. (Ed.), Competition in Global Industries. Boston: Harvard Business School Press, 367-401.

Beamish, P. S. \& Jung, J. C.. (2005). The performance and survival of joint ventures with parents of asymmetric size. Management International, 10(1), 19-30.

Birkinshaw, J., Hood, N. \& Young, S.. (2005). Subsidiary entrepreneurship, internal and external competitive forces, and subsidiary performance. International Business Review, 14, 227-248.

Bjorkman, I., Smale, A., Sumelius, J., Suutari, V. \& Lu, Y.. (2008). Changes in institutional context and MNC operations in China: Subsidiary HRM practices in 1996 versus 2006. International Business Review, 17, 146-158.

Bleeke, J. \& Ernst, D.. (1993). Collaborate to compete. New York: John Wiley and Sons.

Blomqvist, K., Hurmelinna, P., Puumalainen, K. \& Saarenketo, S.. (2005). Striving towards R\&D collaboration performance: The effect of asymmetry, trust and contracting. Creativity and Innovation Management, 14(4), 374-383.

Brannen, M. Y. \& Peterson, M. F.. (2009). Merging without alienating: Interventions promoting cross-cultural organizational integration and their limitations. Journal of International Business Studies, 40, 468-489.

Brouthers, K. D. \& Bamossy, G. J.. (2006). Post-formation processes in eastern and western European joint ventures. Journal of Management Studies, 43(2), 203-229.

Brouthers, K. D., Brouthers, L. E \& Wilkinson, T. J.. (1995). Strategic alliances: Choose your partners. Long Range Planning, $28,18-25$.

Buckley, P. J. \& Casson, M.. (1988). A theory of cooperation in international business. Management International Review, (Special Issue), 19-38.

Cardinal, L., Sitkin, S. B. \& Long, C. P.. (2004). Balancing and rebalancing in the creation and evolution of organizational control. Organization Science, 15(4), 411-431.

Chen, D., Park, S. \& Newburry, W.. (2009). Resource condition and control of international joint ventures. Strategic Management Journal, 30(11), 1133-1156.

Demir, R. \& Soderman, S.. (2007). Skills and complexity in management of IJVs: Exploring Swedish managers' experiences in China. International Business Review, 16, 229-250.

Dess, G. G. \& Robinson, R. B.. (1984). Measuring organizational performance in the absence of objective measures: The case of private-held firm and conglomerate business unit. Strategic Management Journal, 5(3), 265-273.

Dobkin, J. A., Burt, J. A., Krupsky, K. J. \& Spooner, M. J.. (1994). Joint ventures with international partners: Structure and negotiation with forms. Washington, D. C.: Butterworth.

Dong, L. \& Glaister, K.. (2006). Motives and partner selection criteria in international strategic alliances: Perspectives of Chinese firms. International Business Review, 15, 577-600.

Fenton-O’Creevy, M., Gooderham, P. \& Nordhaug, O.. (2008). Human resource management in US subsidiaries in Europe and Australia: Centralisation or autonomy? Journal of International Business Studies, 39, 151-166.

Fey, C. F., Morgulis-Yakushev, S., Park, H. J. \& Björkman, I.. (2009). Opening the black box of the relationship between HRM practices and firm performance: A comparison of MNE subsidiaries in the USA, Finland, and Russia. Journal of International Business Studies, 40, 690-712.

Furuya, N., Stevens, M. J., Bird, A., Oddou, G. \& Mendenhall, M.. (2009). Managing the learning and transfer of global management competence: Antecedents and outcomes of Japanese repatriation effectiveness. Journal of International Business Studies, 40, 200-215.

Ganzach, Y.. (1998). Intelligence and job satisfaction. Academy of Management Journal, 41(5), 526-539.

Garcia-Canal, E. \& Sanchez-Lorda, P.. (2007). One more only if it is one of us. The number of partners and the stock market reaction 
to domestic and international alliance formation in EU telecom firms. International Business Review, 16, 83-108.

Geringer, J. M. \& Hebert, L.. (1989). Control and performance of international joint ventures. Journal of International Business Studies, 20, 235-254.

Geringer, J. M. \& Hebert, L.. (1991). Measuring performance of international joint ventures. Journal of International Business Studies, 22(2), 249-265.

Gupta, N., Shaw, J. D. \& Delery, J. E.. (2000). Correlates of response outcomes among organizational key informants. Organizational Research Methods, 3(4), 323-347.

Hamill, J. \& Hunt, G.. (1993). Joint ventures in Hungary: Key success factors. European Management Journal, 11(2), $238-247$.

Hannan, M. T. \& Freeman, J. H.. (1984). Structural inertia and organizational change. American Sociological Review, $29,149-164$.

Harrigan, K. R.. (1988). Strategic alliances and partner asymmetries. Management International Review, (Special Issue), 53-72.

Hanvanich, S., Miller, S. R., Richards, M. \& Cavusgil, S. T.. (2003). An event study of the effects of partner and location cultural differences in joint ventures. International Business Review, 12, 1-16.

Hill, R. D. \& Hellriegel, D.. (1994). Critical contingencies in joint venture management: Some lessons from managers. Organization Science, 5, 594-607.

Hitt, M. A., Bierman, L., Shimizu, K. \& Kochhar, R.. (2001). Direct and moderating effects of human capital on strategy and performance in professional service firms: A resource-based perspective. Academy of Management Journal, 44(1), 13-28.

Hofstede, G.. (2001). Cultures consequences (2nd ed.). Thousand Oaks, CA: Sage.

Hymer, S. H.. (1976). The international operations of national firms: A study of direct foreign investment. Cambridge, MA: MIT Press.

Indro, D. C. \& Richards, M.. (2007). The determinants of foreign partner's equity ownership in Southeast Asian joint ventures. International Business Review, 16, 177-206.

Inkpen, A. C. \& Currall, S. C.. (2004). The coevolution of trust, control, and learning in joint ventures. Organization Science, 15(5), 586-599.

Kabiraj, T., Lee, C. C. \& Marjit, S.. (2005). Cultural compatibility and joint venture instability: A theoretical analysis. Indian Economic Review, 40(2), 209-220.

Kabiraj, T. \& Chowdhury, P. R.. (2008). Adoption of new technology and joint venture instability. Research in International Business and Finance, 22, 108-123.

Katz, D. \& Kahn, R.. (1978). The social psychology of organizations. New York: Wiley.

Killing, J. P.. (1983). Strategies for joint venture success. New York: Praeger.

Langfred, C. W.. (2004). Too much of a good thing? Negative effects of high trust and individual autonomy in self-managing teams. Academy of Management Journal, 47(3), 385-399.

Law, K. S., Song, L. J., Wong, C. S. \& Chen, D.. (2009). The antecedents and consequences of successful localization. Journal of International Business Studies, 40, 1359-1373.

Law, K. S., Tse, D. K. \& Zhou, N.. (2003). Does human resource management matter in a transitional economy? China as an example. Journal of International Business Studies, 34, 255-265.

Levy, O., Beechler, S., Taylor, S. \& Boyacigiller, N. A.. (2007). What we talk about when we talk about "global mindset”: Managerial cognition in multinational corporations. Journal of International Business Studies, 38, 231-258.

Lovett, S. R., Perez-Nordtvedt, L. \& Rasheed, A. A.. (2009). Parental control: A study of U.S. subsidiaries in Mexico. International Business Review, 18, 481-493.

Luo, Y.. (2003). Market-seeking MNEs in an emerging market: How parent-subsidiary links shape overseas success. Journal of International Business Studies, 34(3), 290-309.

Luo, P. \& Park, S.. (2004). Multiparty cooperation and performance in international equity joint ventures. Journal of International Business Studies, 35(2), 142-160.

Luo, Y., Shenkar, O. \& Nyaw, M.. (2001). A dual parent perspective on control and performance in international joint ventures. Journal of International Business Studies, 32(1), 41-58.

Lyles, M. A. \& Reger, R. K.. (1993). Managing for autonomy in joint ventures: A longitudinal study of upward influence. Journal of Management Studies, 30, 383-404.

Madhok, A.. (2006). Revisiting multinational firms' tolerance for joint ventures: A trust-based approach. Journal of International Business Studies, 37, 30-43.

Meschia, P. X. \& Riccio, E. L.. (2008). Country risk, national cultural differences between partners and survival of international joint ventures in Brazil. International Business Review, 17, 250-266.

Mohr, A. T. \& Puck, J. F.. (2005). Managing functional diversity to improve the performance of international joint ventures. Long Range Planning, 38, 163-182. 
Newburry, W. \& Zeira, Y.. (1999). Autonomy and effectiveness of equity international joint ventures: A comparative analysis of Hungary and Britain. Journal of Management Studies, 36, 263-285.

Newburry, W., Zeira, Y. \& Yeheskel, O.. (2003). Autonomy and effectiveness of equity international joint ventures (IJVs) in China. International Business Review, 12(4), 395-419.

Nielsen, B. B.. (2007). Determining international strategic alliance performance: A multidimensional approach. International Business Review, 16, 337-361.

Nippa, M., Beechler, S. \& Klossek, A.. (2007). Success factors for managing international joint ventures: A review and an integrative framework. Management and Organization Review, 3(2), 277-310.

Osland, G. E. \& Cavusgil, S. T.. (1998). The use of multiple-party perspectives in international joint venture research. Management International Review, 38(3), 191-202.

Parkhe, A.. (1991). Interfirm diversity, organizational learning, and longevity in global strategic alliances. Journal of International Business Studies, 22, 579-601.

Paterson, S. L. \& Brock, D. M.. (2002). The development of subisidary-management research: Review and theoretical analysis. International Business Review, 11, 139-163.

Pfeffer, J. \& Salancik, G. R.. (1978). The external control of organizations: A resource dependence perspective. New York: Harper \& Row.

Prahalad, C. K. \& Doz, Y. L.. (1987). The multinational mission. Free Press.

Rugman, A. M. \& Oh, C. H.. (2010). Does the regional nature of multinationals affect the multinationality and performance relationship? International Business Review, forthcoming. doi:10.1016/j.ibusrev.2009.02.012

Salk, J. E. \& Shenkar, O.. (2001). Social identities in international joint ventures. Organization Science, 12(2), 161-178.

Scarpello, V. \& Campbell, J. P.. (1983). Job satisfaction: Are all the parts there? Personnel Psychology, 36(3), 577-600.

Shenkar, O. \& Zeira, Y.. (1987). Human resources management in international joint ventures: Directions for research. Academy of Management Review, 12, 546-557.

Shenkar, O. \& Zeira, Y.. (1992). Role conflict and role ambiguity of chief executive officers in international joint ventures. Journal of International Business Studies, 23(1), 55-75.

Taggart, J. H.. (1999). MNC subsidiary performance, risk, and corporate expectations. International Business Review, 8, $233-255$.

Taggart, J. H. \& Hood, N.. (1999). Determinants of autonomy in multinational corporation subsidiaries. European Management Journal, 17(2), 226-236.

Tallman, S.. (2009). Global strategy. UK: Wiley.

Trevino, L. J., Thomas, D. E. \& Cullen, J.. (2008). The three pillars of institutional theory and FDI in Latin America: An institutionalization process. International Business Review, 17, 118-133.

Vachani, S.. (1999). Global diversification's effect on multinational subsidiaries' autonomy. International Business Review, 8, 535-560.

Wang, J., Liu, X. \& Li, X.. (2009). A dual-role typology of multinational subsidiaries. International Business Review, 18, 578-591.

Wang, Y. \& Nicholas, S.. (2007). The formation and evolution of non-equity strategic alliances in China. Asia Pacific Journal of Management, 24, 131-150.

Yamin, M. \& Golesorkhi, S.. (2010). Cultural distance and the pattern of equity ownership structure in international joint ventures. International Business Review, forthcoming. doi:10.1016/j.ibusrev.2009.11.004.

Yeheskel, O., Zeira, Y., Shenkar, O. \& Newburry, W.. (2001). Parent-company dissimilarity and equity international joint venture (EIJV) effectiveness. Journal of International Management, 7(2), 81-104.

Young, S. \& Tavares, A. T.. (2004). Centralization and autonomy: Back to the future. International Business Review, 13, $215-237$.

Zaheer, S. \& Mosakowski, E.. (1997). The dynamics of foreignness: A global study of survival in financial services. Strategic Management Journal, 18(6), 439-464.

Zeira, Y. \& Parker, B.. (1995). International joint ventures in the United States: An examination of factors related to their effectiveness. The International Executive, 37(4), 373-393.

Zeira, Y. \& Shenkar, O.. (1990). Interactive and specific parent characteristics: Implications for management and human resources in international joint ventures. Management International Review, 30 (Special Issue), 7-22.

Zhang, Y. \& Li, H.. (2001). The control design and performance in international joint ventures: A dynamic evolution perspective. International Business Review, 10, 341-362.

(Edited by Ruby and Chris) 